\title{
INVESTIGATION OF THE MONETARY POLICY PRACTICES IN 2001 AND 2008 TURKISH CRISES
}

\author{
Semra TAŞPUNAR ALTUNTAŞ ${ }^{1}$
}

\begin{abstract}
The rapid financialization of the world economy after eighties, brought with it increasingly widespread economic crises. These crises, which are originated from financial markets in general, have brought shrinkage and depression in the real economy. In the beginning, the crises were reacted with the channels of monetary policy. However, the spread of the crises to the long term, the failure of the applied monetary policies to create the desired effect, led to negative views towards monetary policies and therefore central banking. Two major economic crises in Turkey over the past two decades have led policy makers and academics to rethink the views of macroeconomics and monetary policy. The nature of the relationship between the Central Bank's inflation and the alternative monetary policy instruments used in Turkey during the research period is analyzed comparatively in the context of 2001 and 2008 crisis periods. While the effect of monetary policy variables on price is investigated using the ARDL boundary test method in the framework of the forecasting model created for this purpose, policy breakdowns and price breaks are investigated with multiple structural breakdown test. The shocks that are common in countries dependent on foreign economies such as Turkey, foreign dependency and foreign capital inflows, which are typical characteristics of these economies, remove the applied monetary policies. It is thought that there is not a stable and predictable relationship between inflation and monetary policy instruments in Turkey. Thus, starting from the hypothesis that there is no stable and predictable relationship between inflation and monetary policy instruments in Turkey, in the framework of crisis periods in 2001 and 2008, investigations into whether monetary policy applications are effective in predicting and directing crises. The relationship between the policy changes during the period 1999-2015 and the structural breaks in the variables will be examined and the effectiveness of the monetary policy variables will be tested in terms of price stability.
\end{abstract}

Keywords: Monetary Policy, Crisis, Financial Economy, Structural Breaks

\footnotetext{
${ }^{1}$ Arş. Grv. Dr., İstanbul Üniversitesi, İşletme Fakültesi, Finans Anabilim Dalı, staspunar(at)istanbul.edu.tr
} 


\title{
PARA POLITIKASI UYGULAMALARININ 2001 VE 2008 TÜRKIYE KRIZLERI AÇISINDAN INCELENMESi
}

\begin{abstract}
$\ddot{o z z}$
Dünya ekonomisinde seksenli yıllardan sonra yaşanan hızlı finansallaşma, gittikçe artan ve yaygın hale gelen ekonomik krizleri beraberinde getirmiştir. Genel olarak finansal piyasalar kaynaklı olan bu krizler, reel ekonomide daralma ve durgunluğu da beraberinde getirmiştir. Başlangıçta para politikası kanallarıyla krizlere tepki verilmiş; ancak krizlerin uzun vadeye yayılması, birçok dünya ülkesini etkilemesi ve uygulanmış olan para politikalarının istenen etkiyi yaratmaması, para politikalarına ve dolayısıyla da merkez bankacılığına yönelik olumsuz görüşlere sebep olmuştur. 2000li yıllarda Türkiye'de yaşanan iki büyük ekonomik kriz, politika uygulayıcıların ve akademisyenlerin makroekonomi ve para politikası görüşlerini yeniden düşünmelerine yol açmıştır. Merkez Bankası'nın enflasyon ile Türkiye'de araştırma döneminde kullanmış olduğu alternatif para politikası araçları arasındaki ilişkinin niteliği, 2001 ve 2008 kriz dönemleri bağlamında karşılaştırmalı olarak analiz edilmektedir. $\mathrm{Bu}$ amaçla oluşturulan tahmin modeli çerçevesinde para politikası değişkenlerinin fiyat üzerindeki etkisi ARDL sınır testi yöntemi kullanılarak araştırılırken, bir taraftan da çoklu yapısal kırılma testi ile politika değişkenleri ve fiyatta meydana gelen kırılmalar incelenmektedir. Türkiye gibi dış ekonomilere bağımlı ülkelerde sıklaşan şoklar, bu ekonomilerin tipik özelliği olan dışa bağımlılık ve yabancı sermaye girişleri, uygulanan para politikalarını etkinlikten uzaklaştırmaktadır. Türkiye'de enflasyon ile para politikası araçları arasında istikrarlı ve öngörülebilir bir ilişkinin olmadığı düşünülmektedir. Böylelikle, dışa açık bir ülke olan Türkiye'de, enflasyon ile para politikası araçları arasında istikrarlı ve öngörülebilir bir ilişkinin olmadığ 1 hipotezinden yola çıkılarak; 2001 ve 2008'de meydana gelen kriz dönemleri çerçevesinde, irdelenen para politikası uygulamalarının, krizleri öngörmek ve yönlendirmek konusunda etkin olup olmadığı araştırılmaktadır. Çalışma doğrultusunda 1999-2015 yılları arasındaki dönemdeki politika değişiklikleri ve değişkenlerde ortaya çıkan yapısal kırılmalar arasındaki ilişkiler incelenecek ve para politikası değişkenlerinin fiyat istikrarı doğrultusunda etkinliği test edilecektir.
\end{abstract}

Anahtar Kelimeler: Para Politikası, Kriz, Finansal Ekonomi, Yapısal Kırılma

Taşpunar Altuntaş, Semra. "Investigation of the Monetary Policy Practises in 2001 and 2008 Turkish Crises". ulakbilge 5. 15 (2017): 1395-1412

Taşpunar Altuntaş, S. (2017). Investigation of the Monetary Policy Practises in 2001 and 2008 Turkish Crises. ulakbilge, 5 (15), s.1395-1412. 


\section{Introduction}

The rapid financial growth experienced in the economy in recent years has brought with it increasing economic crises. Most of the crises are caused by financial markets. As a result of this, the recession has occured in the economy. The main problem in the economy is the real economic recession caused by this instability rather than financial instability. The reactions given to the economic crises in the first place were realized with the monetary policy channel. But the long duration of the crises and the failure of the applied monetary policies to create the anticipated effects in times of crisis have led to increased criticism of central banking and monetary policies.

It is difficult to manage monetary policies in the triangle of inflation, production and finance. While monetary policy decisions were made by central banks for a long time, only price stability was taken into account. This view has changed after the 2008 global crisis, and in addition to the benchmark interest rates used as a policy instrument, it has become necessary to develop a number of policy instruments. For this reason, they have implemented policies that provide financial stability as well as price stability.

In theory, the question of whether the policy rate instrument is effective or not is under discussion at the point of controlling inflation. However, in practice, with the development of financial markets, it is examined whether the monetary transmission channels operate effectively. In this context, two major economic crises in Turkey in the 2000s led to the rethinking of macroeconomic policy views of theorists and policy makers in general, and of monetary policy views in more detail. It is seen that the monetary policy strategy in Turkey has been redesigned after the crisis of 2001, which is mainly caused by internal shocks, and the crisis of 2008, which is caused by external shocks.

The domestic economic crisis that Turkey experienced in 2001 led the Central Bank to abandon the exchange rate targeting and fixed exchange rate regime. At that time, preparations for the transition to the inflation targeting strategy, which is widespread in the international economy, began. In the first stage, the application of flexible exchange rate has been started and it has been aimed to provide necessary macroeconomic conditions by forming an intermediate period with implicit inflation targeting. Positive developments in macroeconomic indicators and structural regimes for central banking during the transition period led to the introduction of explicit inflation targeting in 2006. The reflection of the 2008 financial crisis on the global scale against the Turkish economy as a real crisis despite the domestic crisis in 2001 showed that inflation targeting and price stability are not sufficient for 
macroeconomic stability. The 2008 crisis caused another major change in the monetary policy of the Central Bank in 2010, and macro-prudential policy was included in the current monetary policy framework.

The study seeks to examine the transformation of central banking and monetary policy in Turkey in the context of two major economic crises. Monetary policy applications are expected to contribute to the steady growth of the economy and the transmission channels by influencing the changes in interest rates, exchange rates and money supply. Central banks change the nature of monetary liabilities by changing the assets of their indirect and direct monetary policy instruments and their bilateral securities. It affects the level of liquidity in the economy and thus drives the economy. The nature of the relationship between the alternative monetary policy tools used by the Central Bank in Turkey and inflation is analyzed comparatively in the context of 2001 and 2008 crisis periods. For this purpose, the effect of the monetary policy variables on the price is investigated using the ARDL boundary test method within the framework of the forecasting model.

\section{Literature}

Analyzing the contraction and recovery periods using the VAR model, Çetin (2005) determined that the interest rate and real exchange rate shock negatively affect the economic fluctuations and that the stock price shock and the foreign investor influence positively.

Özata (2007) analyzed the effects of shocks on the Turkish economy with the VAR model using quarterly data for 1987-2005. The results show that shocks at global interest rates have a negative impact on real exchange rate. Nevertheless, it was seen that short-term foreign sources coming to the country due to the relatively high interest rates in Turkey led to overvaluation of the TL. In the study, it was also found that the increase and decrease of money supply on inflation were effective and the shocks of supply and demand did not affect inflation as much as expected. Özata (2007) explains this situation with the inflation problem, tight money policies and very frequent economic crises in the related years.

Akyazı and Ekinci (2009) used the monthly Granger causality analysis to show that trying to reduce inflation by using monetary policy only caused the Turkish economy to enter a recession risk in their studies examining inflation and growth relations using monthly data.

Kadioglu (2006) found that contrary to the traditional economic theory, contrary to the traditional economic theory, the increase in interest rates in Turkey 
caused increase in demand for domestic assets and appreciation of TL due to foreign capital inflows, while inflation tended to decrease due to decreasing import costs. This suggests that the relationship between monetary policy and aggregate demand is less in Turkey than in developed countries.

In Kademli's (2007) study, he analyzed how he reacted to shocks in interest rates, bank loans and foreign exchange money supply using the three-month period of 1990-2006 and the VAR model. Analyzes in the study have shown that interest rates give short, cyclical and meaningful responses to money shocks. The bank has given brief but weak responses to shocks of money supply shocks, and the exchange rate reaction is incompatible with the theory and meaningless.

Örnek (2009) investigated the impact of monetary policy shocks on the real economy and prices by examining the money transfer channels in his study using the VAR model with 1990-2006 data. The studies used for the three-month period 19902006 showed that the exchange rate and interest rate channels worked by the stock and bank credit channels did not give meaningful results.

Yaprakl1 and Kaplan (2012) reported that the TCMB's interventions on foreign exchange and the application of monetary policy against interest and exchange rates should be made more careful and transparent due to the effects of interest, exchange rate and inflation on each other, otherwise this would harm monetary policy.

In his study using the ARDL method of Düzgün (2010), the 1987-2007 period used a three month wide money supply $(\mathrm{M})$ as a monetary policy variable and public expenditure as a fiscal policy variable. The results of the research show that the monetary policy on the economy is meaningless and the public expenditure has a negative effect. In both cases the Monetarist view shows validity. The significance of the monetary policy and the meaningful fiscal policy indicate that the expansionary fiscal policies are more effective on the Turkish economy because of the budget deficit and the interest rate.

Koyuncu (2009) showed that the 1987-2007 period was the most important variable explaining the current account deficits in the economy and the tightening in the doctoral dissertation using the VAR method with the quarterly data. Outputs in the study show that if the monetary policies are active, they will increase prices if they are expanding, and if they are constricted, they will cause stagnation. This situation prevents the politics from being influenced by real variables like employment.

Kasapoğlu (2007) showed that in his study with three months data of the 19902006 period using the VAR model, he significantly affected the price level of the 
exchange rate, which he did not affect the level of production of the exchange rate. This situation seems to be caused by the positive effect of exports on the effects of import foreign exchange shock, but it is seen that increasing the cost of import input and the prices of final goods caused direct and cost price increases in exchange rate shock.

The model also failed to obtain significant findings for the study of stocks and credit channels. This is due to the fact that the stock market is not deep by the author and that the banking sector after the 2001 crisis has been restructured.

Çetin and Çetin (2007) show that monetary and fiscal policies affect macroeconomic variables using VAR analysis, while real exchange rate and inflation are positive and real GDP is negatively affected if the interest rate is used as a monetary policy. In the case of using money supply as a monetary policy, the debt ratio is positively reacting. This shows that the interest rate is effective as an instrument of monetary policy.

Kazgan (2012) points out that the positive economic developments in Turkey during 2002-2006 are realized by the effects of global developments rather than domestic policies. This situation is also supported by the real crisis that started to be seen from the last quarter of 2008 after the global crisis.

Filho (2010) analyzed comparatively the monetary policies of the countries that implemented and did not implement the inflation targeting policy during the 2008 global crisis. It has been found that the employment and GDP performances of the countries that implement the inflation targeting are more successful than the countries that do not implement the inflation targeting policy and that it is easier to overcome the stagnation hazard.

\section{Methodology}

Time series analysis, which is defined as a sequence of measurements observed over time and finds a wide application area within the framework of applied econometrics, is summarized as determining the probability structure of the time series and predicting the future state or determining the relationships between multiple time series. Whether or not a stochastic process unit root, which defines an economic time series, carries the root is an important question that is closely related to the economic equilibrium analysis. Many reasons, especially the economic crisis, can cause structural breaks in the time series, which makes the analysis process difficult. Therefore, it is necessary to theoretically introduce these practical processes, including the basic econometric method of studying in this section. 


\section{Unit Root Test}

In the regression analysis conducted with the time series data, historical relations between past and future values are shaped by the concept of stationarity. The stability of the time series means that the variance and the mean are constant over time and that the covariance of the variables in the delayed two time periods depends on the delay between the variables and not on time. In the event that the stationary condition can not be achieved, the time series is trendy. The non-stationarity of the time series leads to a stochastic or deterministic trend. False regression-like deceptive situations arise in model estimates and regression equations in which time series with these properties are used (Stock and Watson, 2011: 549).

In order to reach meaningful results in econometric analyzes to be made over time series and to be able to talk about a meaningful long-term relationship between the variables, the series have to be stationary. In other words, the characteristics of variables such as mean and variance should not change over time. Most of the economic time series can follow a non-stationary course over time due to the influence of various factors. Non-stationary time series are generally stationary when the first or second differences are taken (Karagöz and Ergün, 2010: 177-178). However, a second stationary sequence is called weak stationary. The series, which exhibit stationary features, carry little information about the past, and any choke effect is temporary. The non-stationary series, on the other hand, have a lasting effect on the chokes (Elma, 2008: 9). The goal of the stabilization process is to remove the effects of the permanent shocks that are contained in the series and to ensure that only temporary shocks remain. When a time series contains a unit root, it means that the series is not static.

The most commonly used test in the applied literature to determine the integration ratios of time series is the Augmented Dickey-Fuller (ADF) test developed by Dickey and Fuller. The ADF test assumes that error terms have statistically independent and constant variance. For this reason, it is necessary to make sure that there is no correlation between the error terms and that they have a constant variance when performing the ADF test. ADF and Phillips-Perron (PP) tests are quite sensitive to delays (Kutlar, 2005: 307308). Although there are many unit root tests developed by Kwiatkowski, Phillips, Schmidt, and Shin (1992) in the literature, expressed as KPSS test and including an alternative unit root test, in which the null hypothesis has no unit root, only the ADF and PP tests And the Zivot-Andrews fractured unit root test. 


\section{ARDL Boundary Test}

There are many methods that test whether there is a long-term cointegration relationship between time series. The cointegration analysis was developed to demonstrate whether the long spin linear compositions of multiple non-stationary time series are stationary. The introduction of an integrated structure between the two time series also proves the long-term equilibrium relations of these series (Gujarati, 2006: 730).

Among these methods, Engle-Granger (1987), Stock-Watson (1988) and Johansen-Juselius (1990) cointegration tests are most commonly used. However, the variables used in these tests have to be stable at the same level (Düzgün, 2010: 234). Because variables need to be static to be able to talk about a meaningful long-run relationship between variables. Despite this run, most of the economic time series can follow a non-stationary course over time due to the effects of various factors. Nonstationary time series can become stationary at different levels when their differences are taken (Karagöz et al., 2010: 177).

The ARDL approach developed by Pesaran and Shin (1999) and Pesaran et al. (2001) is used in the presence of stationary series at different levels. This test suggests that even though the variables are stationary at different levels, there may be a cointegration relationship. The ARDL approach allows the stationary levels of the time series to be I ( 0 ) or I (1). This approach allows for strong results in small samples. The analysis method that allows model variables to have different delay lengths can present both short and long term relationships at the same time (İlgün, 2010: 241). Together with the error correction model (ECM), short-term dynamics and long-run equilibrium can be integrated without losing long-term knowledge (Pesaran et al., 2001: 290).

In the Pesaran et al. (1996: 3-4), the significance of the level delays of the variables in the error correction form is tested by the Wald or F test so that the longterm relationship obtained can be valid when introducing a variable ARDL (p, q1,..., qn). In this context, the ARDL process consists of three steps. The first stage is based on the application of the Wald or F test to the following unrestricted error correction model given by Pesaran et al. (1996), and thus the search for the existence of a longrun relationship between variables.

The long-term equation of the variable ARDL (p, q1, .., qn) predicted by Pesaran et al. (1996) is estimated after obtaining long-term correlation between variables. The values in parentheses are the optimal delay lengths determined according to statistical criteria for the variables in the model. In the ARDL model, 
critical values such as Akaike (AIC), Schwarz-Bayesian (SBC), and Hannan-Quinn are used to determine the appropriate number of delays and the model is estimated using the delay numbers that provide the smallest information criterion. SBC is generally recommended because it gives a lower delay in the literature (Pahlavani, 2005; Karagöz et al., 2010: 179).

In this case, if the model with the delay length that is the smallest selected critical value does not contain the autocorrelation problem, the delay length that provides the second smallest critical value should be taken. If necessary, this process should continue until the problem of autocorrelation has occurred. Since the dependent variable in the model also has a lagged value, the Breusch-Godfrey autocorrelation test should be used instead of the Durbin-Watson (DW) statistic in the autocorrelation process (Altıntaş et al., 2010: 1720). After the estimates of the long term relationship are obtained, the error correction model is estimated in the third step and the diagnostic statistics are obtained for the obtained ARDL model. Then, the coefficients of the long and short term relationships between the variables are obtained (İlgün, 2010: 242).

\section{Findings}

\section{ADF Unit Root Test}

Based on the literature studies and the targeting strategies applied by the Central Bank, the forecasting model included interest rate, exchange rate and monetary policy variables for money supply. In the model applied, TUFE is used as a dependent variable, which is the ultimate aim of the Central Bank for price stability. The independent variables that were examined for the effects on TUFE were two groups, namely monetary policy variables and control variables. Monetary policy variables in the model are M2 money supply, overnight monetary base overnight interest rate (ONR) and US dollar denominated purchase rate (US) announced by the CBRT. In the case of the financial markets in the model, net foreign capital inflows (FCI) representing foreign capital movements, BIST 100 index (BIST) according to closing prices and total domestic credit volume $(\mathrm{KH})$ control variables representing banking sector were selected as control variables. The period between 1999 and 2015 is covered by monthly variables. Shadow variables were also included in the model for the crisis periods 2001 and 2008. The logarithmic values of the variables are taken and included in the model.

\footnotetext{
$\operatorname{lnTUFE} E_{\mathrm{t}}=\alpha_{0}+\alpha_{1} \operatorname{lnONR}_{\mathrm{t}}+\alpha_{2} \operatorname{lnABD}_{\mathrm{t}}+\alpha_{3} \ln \mathrm{M}_{\mathrm{t}}+\alpha_{4} \operatorname{lnBIST} \mathrm{T}_{\mathrm{t}}+\alpha_{5} \operatorname{lnKH}_{\mathrm{t}}+$ $\alpha_{6} \operatorname{lnFCI}_{\mathrm{t}}+\alpha_{7} \mathrm{G} 1+\alpha_{8} \mathrm{G} 2+\mathrm{u}_{\mathrm{t}}$
} 
In order to evaluate the performance of the monetary policy during the crisis period, the model used the ARDL method to determine whether short- or long-term relationships exist between variables. The aim of this analysis process is to reveal the effectiveness of monetary policy in Turkey, a small foreign country, in terms of two crises.

The series of variables included in the estimation model were first analyzed by standard unit root tests for the period 1999: 01-2015: 12. Here, for the ADF test, the $\mathrm{H}_{0}$ hypothesis states that the series are not stationary. The alternative hypothesis implies that there is no unit root process in the series. Unit root tests were made for two models, fixed and trendy. The results of the unit root tests of the macroeconomic variables discussed in the forecasting model are as shown in the table below.

Table 1 ADF and PP Unit Root Test Results

\begin{tabular}{|c|c|c|c|c|c|c|}
\hline \multirow[b]{2}{*}{ Variable } & \multirow{2}{*}{$\begin{array}{l}\text { Level/ } \\
\text { First Diff. }\end{array}$} & \multicolumn{2}{|c|}{ ADF Test Statistics } & \multicolumn{2}{|c|}{ PP Test Statistics } & \multirow{2}{*}{ Result } \\
\hline & & Fixed & Trend & Fixed & Trend & \\
\hline \multirow{2}{*}{ TUFE } & Level & $-5,24(1)$ & $-3,44(1)$ & $-8,80(4)$ & $-4,21(4)$ & \multirow{2}{*}{$\mathrm{I}(0)$} \\
\hline & First diff. & $-4,46(0)$ & $-6,23(0)$ & $-4,69(8)$ & $-6,45(7)$ & \\
\hline \multirow{3}{*}{ M2 } & Level & $-2,56(0)$ & $-1,43(0)$ & $-2,56(0)$ & $-1,36(2)$ & \multirow{3}{*}{$\mathrm{I}(1)$} \\
\hline & & $-12,87$ & & & & \\
\hline & First diff. & (0) & $-12,94(0)$ & $-12,63(4)$ & $-12,95(2)$ & \\
\hline \multirow{2}{*}{ ABD } & Level & $-2,23(1)$ & $-2,56(1)$ & $-2,13(3)$ & $-2,25(3)$ & \multirow{2}{*}{$\mathrm{I}(1)$} \\
\hline & First diff. & $-8,42(1)$ & $-8,45(1)$ & $-8,53(2)$ & $-8,53(2)$ & \\
\hline \multirow{2}{*}{ ONR } & Level & $-1,48(3)$ & $-3,67(3)$ & $-1,51(2)$ & $-4,91(5)$ & \multirow{2}{*}{$\mathrm{I}(1)$} \\
\hline & First diff. & $-5,98(2)$ & $-5,89(2)$ & $-20,16(2)$ & $-20,01(2)$ & \\
\hline \multirow{2}{*}{ BIST } & Level & $-2,88(0)$ & $-3,11(0)$ & $-2,65(4)$ & $-3,41(4)$ & \multirow{2}{*}{$\mathrm{I}(1)$} \\
\hline & First diff. & $-9,12(0)$ & $-9,23(0)$ & $-9,04(3)$ & $-9,13(3)$ & \\
\hline \multirow{2}{*}{ КН } & Level & $-1,01(2)$ & $-3,01(5)$ & $-1,12(6)$ & $-1,69(6)$ & \multirow{2}{*}{$\mathrm{I}(1)$} \\
\hline & First diff. & $-4,01(2)$ & $-4,12(2)$ & $-12,20(6)$ & $-12,54(6)$ & \\
\hline \multirow{3}{*}{ FCI } & Level & $-3,76(1)$ & $-5,12(1)$ & $-6,13(7)$ & $-8,34(7)$ & \multirow{3}{*}{$\mathrm{I}(0)$} \\
\hline & & $-14,20$ & & & & \\
\hline & First diff. & (1) & $-14,24(1)$ & $-20,16(2)$ & $-20,05(2)$ & \\
\hline \multirow{2}{*}{\multicolumn{2}{|c|}{ MacKinnon }} & $1 \%$ & $10 \%$ & $5 \%$ & $10 \%$ & \multirow{3}{*}{ rend } \\
\hline & & - & - & - & $\mathrm{T}$ & \\
\hline \multicolumn{2}{|c|}{ Crit. Value } & $3,47 \quad 2,88$ & 2,58 & $+, 01 \quad 3,43$ & 3,14 & \\
\hline
\end{tabular}


According to the ADF unit root test results, the series belonging to the variables were found to be stable at different levels such as I (0) and I (1). From the variables TUFE and FCI series can reject the $\mathrm{H}_{0}$ hypothesis in terms of both fixed and trend values and become stable by reflecting I (0) condition. All other variables in the model can not reject the $\mathrm{H}_{0}$ hypothesis at the level and become static by rejecting the null hypothesis when the first differences are taken. So, the subject variables are in the state of I (1). However, the fact that two major economic crises have occurred in Turkey makes the results of the unbroken unit root test such as the ADF debatable. For this reason, it would be useful to include the fractured unit root test in the analysis.

\section{ARDL ve Cointegration Analysis}

According to the ADF unit root test results, the fact that two of the variables I (0) are stationary at I (1), that is, they are not stable at the same level, prevent the use of traditional methods for integrating variables such as Engle-Granger and Johansen. For this reason, the existence of the cointegration relation between variables is investigated by the ARDL boundary test approach proposed by Pesaran et al. (2001) and allowing for different degrees of integration. The shadow variables (G1 and G2) placed to compare the monetary policy variables in the 2001 and 2008 crisis periods were statistically insignificant and made the model unstable. The reason for this is thought to be the regime change that took place in January 2006. In the new period, which started with the official inflation targeting of the Central Bank in January 2006, it was determined that the series belonging to the variables differed from the previous turn.

The generated forecasting model, without the work done by the waxman (2013: 293), went out of the way and required two round trips. In this context, the prediction model has been tested separately with the ARDL approach over the "Second Semester", defined as "First Semester" and 2006: 01-2015: 12, defined as 1999: 01-2005: Since the ARDL approach allows analysis with low numbers of observations, it is no problem that observations of variables are reduced in this way.

In the process defined as the first period in Turkey, the shadow variable placed in the model representing the 2001 crisis has been removed from the prediction model because it destroys both the model and the results. The hypothesis of cointegration in the first phase of the ARDL is tested. The F statistic used when testing hypotheses is compared with the critical values calculated by Pesaran et al. (2001) and Narayan (2005). According to the results in Table 2 below, the F-statistic was found to be higher than the upper limit of Pesaran et al. (2001) and Narayan (2005). This means that the $\mathrm{H}_{0}$ hypothesis, which suggests that there is no long-run relationship between 
TÜFE and other variables, is rejected. This means that variables can be used as explanatory variables in long-term changes in the TÜFE.

Table 2 First Period 1999-2005 Conintegration Test Results

\begin{tabular}{cccccc} 
& \multicolumn{2}{c}{$\begin{array}{c}\text { Pesaran (2001) } \\
\text { Narayan (2005) }\end{array}$} \\
k & F Statistic & \multicolumn{2}{c}{ Critical Value } & \multicolumn{2}{c}{ Critical Value } \\
Lower & Upper & Lower & Upper \\
bound & bound & bound & bound \\
7 & 4,83 & 2,86 & 4,57 & 2,48 & 3,75
\end{tabular}

In the second part of the test, long term equations are estimated within the framework of the ARDL approach. The ARDL estimates of the coefficients of the long-term relationship for the first round are given in Table 3. Accordingly, in the long run, the exchange rate and M2 money supply seem to have a meaningful effect on consumer prices as expected. Therefore, the exchange rate positively affects consumer prices at a level of $1 \%$ significance. There is a positive correlation $(0,728)$ between the money supply and consumer prices at $1 \%$ significance level. There is no autocorrelation problem in the prediction model.

Table 3 First Period (1999-2005) ARDL Long Term Results

$\begin{array}{lccc}\quad \text { Variable } & \text { Coefficient } & \text { Std. Error } & \text { t-stat. } \\ \text { InONR } & 0,022 & 0,035 & 0,734(0,453) \\ \operatorname{lnABD} & 0,318 & 0,061 & 5,433(0,000) \\ \operatorname{lnM2} & 0,728 & 0,112 & 5,712(0,000) \\ \operatorname{lnKH} & -0,158 & 0,110 & -1,544(0,126) \\ \text { InFCI } & -1,201 & 0,991 & -1,218(0,031) \\ \text { C } & -1,939 & 0,798 & -2,321(0,019) \\ \text { Serial cor. } & 0,887(0,546) & \text { Normality } & 7,583(0,020) \\ \text { Fonk. Str. } & 0,265(0,613) & \text { Heteroscedasticity } & 0,724(0,391)\end{array}$

Findings as a result of the analyzes made suggest that the exchange rate has a positive effect on consumer prices, as expected both in the short and long term. Money supply, on the other hand, is not meaningful in the short term, but it affects consumer prices in a positive way and strongly in the long run. 
As of January 2006, the Central Bank adopted the short-term interest rate as the main policy instrument in the direction of the open inflation target, once the policy structure and the conditions of the financial markets improved. In this direction, money supply has been passivated within the monetary policy. For this reason, in the second period 2006: 01-2015: 12, the M2 variable was removed from the forecasting model. The null hypothesis, which indicates that there is no cointegration in the first period following a similar process, has been tested against the alternative hypothesis that cointegration occurs.

Table 4 Second Period 2006-2015 Conintegration Test Results

\begin{tabular}{|c|c|c|c|c|c|}
\hline \multirow{3}{*}{$\mathbf{k}$} & \multirow{3}{*}{ F Statistic } & \multicolumn{2}{|c|}{ Pesaran (2001) } & \multicolumn{2}{|c|}{ Narayan (2005) } \\
\hline & & Criti & Value & Criti & Value \\
\hline & & $\begin{array}{l}\text { Lower } \\
\text { bound }\end{array}$ & $\begin{array}{l}\text { Upper } \\
\text { bound }\end{array}$ & $\begin{array}{l}\text { Lower } \\
\text { bound }\end{array}$ & $\begin{array}{l}\text { Upper } \\
\text { bound }\end{array}$ \\
\hline 7 & 11,24 & 2,86 & 4,57 & 2,48 & 3,75 \\
\hline
\end{tabular}

Similar to the first period, the $\mathrm{H}_{0}$ hypothesis was rejected, suggesting that there is no long-run relationship between the TUFE and other variables. This means that variables can be used as explanatory variables in long-term changes in the TFP. The ARDL estimates of the long-term correlation coefficients for the second period are given in Table 5. According to these results, in the long term, only domestic credits (KH) seem to have a significant effect on consumer prices. As in the short term, domestic loans in the long run increase the inflation rate as appropriate. Therefore, domestic credits are positively affecting consumer prices at the $1 \%$ level of significance. There is no autocorrelation problem in the estimation model of the second round.

Table 5 Second Period (2006-2015) ARDL Long Term Results

$\begin{array}{lccc}\quad \text { Variable } & \text { Coefficient } & \text { Std. Error } & \text { t-stat. } \\ \text { InONR } & 0,018 & 0,035 & 0,511(0,612) \\ \text { InABD } & 0,040 & 0,121 & 0,348(0,714) \\ \text { InBIST } & 0,075 & 0,120 & 0,613(0,523) \\ \text { InKH } & 0,336 & 0,051 & 6,100(0,000) \\ \text { InFCI } & -0,864 & 0,602 & -1,421(0,152) \\ \text { C } & 2,268 & 1,279 & 1,763(0,081) \\ \text { Serial cor. } & 1,315(0,243) & \text { Normality } & 5,812(0,079) \\ \text { Fonk. Str } & 1,079(0,314) & \text { Heteroscedasticity } & 0,254(0,991)\end{array}$


The fact that the short term interest rate variable (ONR), which became an important monetary policy variable for the CBRT in the second period, did not make sense, revealed that the effect of short term interest rates on aggregate demand was weak. This result shows that the interest channel in Turkey does not operate in a healthy manner.

\section{Results}

In 2000, two different monetary policy strategies such as exchange rate and inflation targeting have been implemented in Turkey. Two important economic crises have been experienced in 2001 and 2008 when discussing the feasibility and effectiveness of these policies. Developing countries, such as Turkey, experiencing post-financial liberalization, permanent structural deficits in saving-investment balances, dealing with persistent unemployment problems and loose control over their financial institutions, are forced to survive crisis cycles. Policy makers should avoid taking precautions for transfer mechanisms that carry external shocks to the country, suggesting that such crises may be repeated in the middle of the night and that monetary policies will remain unresolved.

The Central Bank responded to all kinds of supply and demand shocks that would negatively affect price stability in the post-2001 crisis period. In the second quarter of 2008, the Central Bank responded to the negative supply shock in Turkey due to inflationary concerns, but the negative demand that emerged with the deepening of the global crisis in the last quarter of 2008 started to cut interest rates even if it was late. Nevertheless, an economic decline has occurred in a much larger extent than in the 2001 crisis, when exchange rate targeting was implemented. It has become clear that the effect of short-term interest rates, an important control variable for the CBRT, on aggregate demand is weak.

The aim of the study was to reveal the effectiveness of the monetary policy in Turkey in the 2000s, when the crises were getting harder, in terms of crisis experiences in 2001 and 2008. The empirical analysis based on the hypothesis that there is no stable and predictable relationship between monetary policy instruments and inflation in Turkey has resulted in the fact that the Central Bank is far from being effective in steering the fluctuations and crises that arise. In this context, the variables included in the forecasting model were subjected to the structural fracture test in order to determine the changes in economic policy. Findings obtained with the Bai-Perron test revealed that there were more than one breaks in the 2000s in relation to the variables included in the prediction model in Turkey. According to the Bai-Perron test results, the monetary policy responses of the Central Bank in 2001 and 2008 did not have a positive impact on output, on the contrary, it was seen that the crisis periods had 
negative effects on the output. The fracture in the FCI variable was detected immediately before the 2001 and 2008 crises. It is also the result that the policy rate is not effective in directing fluctuations in consumer prices.

The sharp decline in the external and internal demand of the global crisis led to consumer prices breaking in December 2008, while the breakdown in output occurred in November of the same year. Considering that the interest rate breakdown occurred in January 2009, it is seen that during the crisis, the Central Bank was both late to intervention and the interest rate cuts had no effect on the price and output. Breaks in the 2001 crisis period in March 2000 for the exchange rate, February 2001 for the money supply, and September 2001 for the consumer prices indicated that the exchange rate and money supply were effective in directing prices in the 2001 crisis. According to the results of the ARDL boundary test, in the 2001 crisis period, the consumer prices were reached in the short term only in the direction of foreign currency exchange, in the long run both foreign exchange rate and money supply affected. When the importance attributed to the exchange rate and money supply is taken into consideration by the Central Bank in the mentioned period, the results of this analysis overlap with the conjuncture. According to the analysis results of the 2008 crisis period, no monetary policy was found to be effective on the changing consumer prices, but rather on total and short term loans over the consumer prices. It is an important finding that short-term interest rates do not have an effect on aggregate demand and therefore consumer prices, despite the introduction of explicit inflation targeting in early 2006 and the use of short-term interest rates as a key policy tool. With the internalization of the money supply, the short-term interest rate, which is the policy instrument of the Central Bank, has decreased on the other interest rates and securities on the market.

Developments in the global economy and the rapid development of financial markets have made it easier for the banking sector to feed not only from domestic sources but also from international sources. It has been determined that there is no stable and predictable relationship between interest rate and inflation in monetary policy instruments in Turkey. The Central Bank is far from being active in steering emerging fluctuations and crises through policy interest. Because, in order to increase the effectiveness of the monetary policy, the relations between inflation, exchange rate and money supply should be weakened from one side and the interest rate should be strengthened from the other side.

It is seen that when an assessment is made for Turkey in terms of monetary policy implementations by way of two crises that lived in the 2000s, it is seen that the monetary policy should be loosened in the first stage. Because this policy is needed to reverse the collapse that is experienced in terms of domestic demand and to start 
the exit process from the recession. This policy process may be supported by a fiscal policy in the direction of the Post-Keynesian view, in a way that contributes to the stimulation of internal demand. If the fiscal policy can be reconciled with the monetary policy during the crisis periods, the Turkish economy can be cost less than the recession process. In this respect, the CBRT's policy of inflation targeting during the global crisis period presents an inconsistent policy framework for combating the stagnation. In the face of economic crises, monetary policy can give unpredictable reactions. For this reason, there is not a single truth that can be defended within the framework of monetary policy; This framework can change depending on the macroeconomic status of the countries and their position in other economies.

\section{KAYNAKLAR}

Akyazı, H. ve Ekinci A. (2009). Türkiye'de 2000 Sonrası Uygulanan Para Politikası Stratejilerinin Makroekonomik Performanslarının Değerlendirilmesi, Atatürk Üniversitesi İktisadi Ve İdari Bilimler Dergisi, Cilt: 23, Say1: 1, s.s. 345-362.

Altıntaş, H. ve Taban S. (2010). Türkiye'de İkiz Açık Sorunu Ve Feldsteinhorioka Hipotezi: ARDL Yaklaşımı Ve Nedensellik Araştırması, Turgut Özal Uluslararası Ekonomi Ve Siyaset Kongresi-1, 15-16 Nisan 2010, Küresel Krizler Ve Ekonomik Yönetişim, Malatya: Bildiri Kitab1, s.s. 17041734.

Çetin, A. ve Çetin B. (2007). Alternatif Para Politikası Değişkenlerinde Maliye Politikası, Döviz Kuru Ve Enflasyonun Büyüme Üzerindeki Etkisi, İktisat Işletme Ve Finans, Cilt: 22, Say1: 252, s.s. 123-134.

Düzgün, R. (2010). Türkiye Ekonomisinde Para Ve Maliye Politikalarının Etkinliği, Uluslararası Sosyal Araştırmalar Dergisi, Cilt: 3,Ssayı: 11, s.s. 230-237

Elma, Ç. A. (2008). Yapısal Kırılmalar Altında Birim Kök Testleri Ve Eşbütünleşme Analizi: Para Talebi İstikrarı, Yüksek Lisans Tezi, Gazi Üniversitesi Sosyal Bilimler Enstitüsü, Ekonometri Anabilim Dalı, Ankara.

Filho, I. C. (2010). Inflation Targeting And Crisis: An Empirical Assessment, IMF Working Paper, No: wp/10/45, http://mpra.ub.uni-muenchen.de/19960/, erişim tarihi: 26.04.2017.

Gujarati, d. (2006). Temel Ekonometri, Literatür Yayıncılık, İstanbul. 
İlgün, M. F. (2010), Genişletici Mali Daralma Hipotezinin Temelleri Ve Türkiye Ekonomisi Üzerine Bir Uygulama, Erciyes Üniversitesi İktisadi Ve İdari Bilimler Fakültesi Dergisi, Say1: 35, s.s. 233-253.

Kademli, S. (2007). Para Politikalarının Reel Ekonomiye Etkisinde Aktarım Mekanizmalarının İşleyişi Ve Türkiye İçin Test Edilmesi, Yüksek Lisans Tezi, Mersin Üniversitesi Sosyal Bilimler Enstitüsü, İktisat Anabilim Dalı, Mersin.

Kadıŏlu, F. (2006). Parasal Aktarım Mekanizmast: Türkiye Örneğinin Yapısal Model Çerçevesinde Analizi, Uzmanlık Yeterlilik Tezi, TCMB Araştırma Ve Para Politikası Genel Müdürlüğü, Ankara.

Karagöz, K. ve Ergün S. (2010). Türkiye'de Ekonomik İstikrarsızlığın Kaynakları: Ekonometrik Bir Değerlendirme, Süleyman Demirel Üniversitesi İktisadi Ve İdari Bilimler Fakültesi Dergisi, Cilt: 15, Sayı: 2, s.s. 169-185.

Kasapoğlu, Ö. (2007). Parasal Aktarım Mekanizmaları: Türkiye Iç̧in Uygulama, Uzmanlık Yeterlilik Tezi, Türkiye Cumhuriyet Merkez Bankası Piyasalar Genel Müdürlüğü, Ankara.

Kazgan, G. (2012). Türkiye Ekonomisinde Krizler (1929-2009) "Ekonomi Politik” Açısından Bir İrdeleme, 3. Baskı s.s. 217, İstanbul Bilgi Üniversitesi Yayınları

Koyuncu, F. T. (2009). Türkiye'de Konjonktürel Dalgalanmaların Arz Ve Talep Şokları İle Analizi, Doktora Tezi, Anadolu Üniversitesi Sosyal Bilimler Enstitüsü, İktisat Anabilim Dal, Eskişehir.

Kutlar, A. (2005). Uygulamalı Ekonometri, 2. Baskı, Ankara: Nobel Yayın Dağıtım.

Örnek, İ. (2009). Türkiye'de Parasal Aktarım Mekanizması Kanallarının İşleyişi, Maliye Dergisi, Sayı: 156, s.s. 104-125.

Özata, E. (2007). Türkiye'de Konjonktürel Dalgalanmaların Zaman Serisi Analizi, Doktora Tezi, Anadolu Üniversitesi Sosyal Bilimler Enstitüsü, İktisat Anabilim Dalı, Eskişehir.

Pahlavanı, M. (2005), Analysing The Trade-Gdp Nexus In Iran: A Bounds Testing Approach, Faculty Of Business Economics Working Papers, No: 05/25, http://ro.uow.edu.au/cgi/viewcontent.cgi?article=1132\& context=commwkpapers, erişim tarihi: 05.04.2017.

Pesaran, M. H. and Shın Y. (1999). An Autoregressive Distributed Lag Modelling Approach To Cointegration Analysis, ed: s. Storm, Econometrics And Economics Theory in the 20th Century, s.s. 134-150. 
Pesaran, M. H., shın, Y. and Smith R. J. (2001), Bounds Testing Approaches To The Analysis Of Level Relationships, Journal Of Applied Econometrics, Vol: 16, s.s. 289-326

Stock, j. H. and. Watson W. (2011). Ekonometriye Giriş, Çev: b. Saraçoğlu, Ankara: Efil Yayınevi.

Yaprakl1, S. Ve Kaplan F. (2012). Türkiye'de Uygulanan Açık Enflasyon Hedeflemesi Stratejisinin Başarısı Üzerine Ekonometrik Bir Değerlendirme, Hacettepe Üniversitesi İktisadi Ve İdari Bilimler Fakültesi Dergisi, Cilt: 30, Sayı: 2, s.s. 185-208. 